\title{
GIS-based approach qualitative features of sub-surface water from coastal district in Andhra Pradesh
}

\author{
Manoj Kumar Karnena ${ }^{1} \cdot$ Madhavi Konni $^{2}$. Bhavya Kavitha Dwarapureddi ${ }^{1}$ Yalakala Satyanarayana ${ }^{1}$. \\ Vara Saritha' ${ }^{10}$
}

Received: 24 April 2021 / Accepted: 16 September 2021 / Published online: 11 February 2022

(c) The Author(s) 2022

\begin{abstract}
Quality of water, along Mandal headquarters of a coastal district of Andhra Pradesh, India, was assessed prior to and past rainfall season to determine water's acceptability for consumption using water quality index (WQI). The present work involved collecting groundwater samples from Mandal headquarters' locations present in the entire district. All the samples were analysed in a comprehensive way for ten physicochemical parameters, including $\mathrm{pH}$, magnesium, calcium, chloride, sulphate, nitrates, total dissolved solids, fluoride, potassium, and sodium. The geographical information system was used for mapping sampling sites. The coordinates of sample collection areas were recorded employing GPS. Correlation matrices for cation-anion were illustrated and from the qualitative results of the samples. Results indicate that WQI prior and past-rainfall seasons ranged from 37.53 to $312.46 ; 42.04$ to 211.89 in 2016, while for 2017, these were in the range of 25.01 to $137.06 ; 30.06$ to 228.83 . The present study's WQI values indicate that the water samples possess poor quality, and no fluoride contaminations were observed. The analysis suggests appropriate treatment of sub-surface water from the study site before consumption.
\end{abstract}

Keywords Water quality index · Ground water · Remote sensing $\cdot$ Environmental pollution

\section{Introduction}

Among the sources of water available, the source catering to the needs of water for consumption, agricultural activities, and industrial drives in semi-arid and arid zones of several nations is groundwater. Across the globe, nearly $65 \%$ caters to consumption, $20 \%$ is used for livestock and irrigation, while for industries and mining activities, $15 \%$ is used (Taloor et al. 2021; Gautam et al. 2017; Falkenmark and Rockström 2006), about one-third of the population across the globe is dependent on groundwater for consumption (Jakeman et al. 2016; Gautam et al. 2016; Adimalla

Manoj Kumar Karnena

manojkumarenviron@gmail.com

Vara Saritha

vsjr08@gmail.com

1 Department of Environmental Science, GITAM Institute of Science, GITAM (Deemed To Be) University, Visakhapatnam 45, India

2 Department of Basic Sciences and Humanities, Dadi Institute of Engineering and Technology, Visakhapatnam, India and Venkatayogi 2018) precisely in developing countries like China and India. Several factors govern groundwater dependence, such as population explosion, enhanced agricultural and industrial activities, inadequate water supply, and other miscellaneous requirements. Owing to the importance and need of this supply, it becomes mandatory to monitor the quality along with the quantity of groundwater (Silva et al. 2021; Sinha et al. 2021; Asano and Cotruvo 2004).

It is understood that the hydrochemistry of groundwater in semi-arid zones is governed by factors such as geology, hydrogeology, precipitation, evaporation, interactions among rock and water, dissolution of minerals, the process of weathering, chemical fertilizers from cultivation, industrial effluents, and several anthropogenic activities (Karunanidhi et al. 2021; Adimalla 2021). Good water quality is essential for the expansion of agricultural and human health (Adimalla and Wu 2019). Many groundwater suitability studies have been carried out across the globe and presented that evaporation and interaction among water and rock are the primary sources for contamination of groundwater precisely in North-eastern Tunisia (Dişli 2017). It was reported that evaporation of groundwater tends to influence 
the development of sulphate-type contamination in semiarid zones of North-west China (Adimalla and Taloor 2020; Ram et al. 2021). Over misuse of groundwater is one of the biggest problems in several parts of the world, among which India is one. It has been reported that groundwater extraction in India annually is the maximum in the world that surpasses China and the USA (Adimalla et al. 2020).

The deterioration of groundwater in India is attributed to improper management strategies for groundwater, mismanagement of wastes, growing population, enhanced industrial and urban development, uncontrolled use of fertilizers, improper dumping of municipal wastes, and dumping yards (Rupal et al. 2012; Palanisamy et al. 2007). The decline of groundwater, specifically in semi-arid and arid zones of India, is attributed to high evaporation rates, erratic rainfall, along over-exploitation; on the other hand, there has been a considerable increase in the call for fresh and potable drinking water leading to water calamity in several parts of the nation (Sakram and Adimalla 2018). Understanding the hydrochemical properties of groundwater helps in rating its appropriateness for various purposes (Adimalla and Wu 2019). Several researchers have conducted studies and have contributed significant information; for instance, multivariate statistical analysis and geochemical modelling conducted by Singh et al. 2017 presented that interaction among rock and water, ion exchange, and weathering were crucial factors responsible for governing the quality of groundwater. A study conducted by Raju et al. 2016 using geostatistical techniques on groundwater quality in hard rock aquifers of Andhra Pradesh, specified that extreme use of pesticides and fertilizers was chiefly responsible for reduced groundwater quality and quantity spatiotemporally. Hydrogeochemical characterization of groundwater quality in Telangana and Tamil Nadu using water quality index and geographic information system (GIS) presented that GIS is an efficient tool for identifying unpolluted and polluted zones (Duraisamy et al. 2019).

Over the decades, the science of geoinformatics has emerged as a significant technology for decision-making in various disciplines (Adimalla and Taloor 2020; Jasrotia et al. 2018). Several researchers have carried out studies towards assessing the spatial distribution of groundwater across the world (Jasrotia and Kumar 2014) and have constructively documented the information using GIS (Jasrotia et al. 2013, Dhar et al. 2017). Several authors have researched groundwater using GIS technology (Jasrotia and Kumar 2014; Cortes et al. 2016) towards accelerating sustainable development (Jasrotia et al. 2019).

Indian coastal aquifers and other parts of the world have reported being the worst affected due to over-exploitation, population explosion, and tremendous industrialization in coastal zones threatening coastal freshwater resources and rendering groundwater non-potable. The presence of major cations and anions in groundwater directly influences its quality. Detailed knowledge of water quality is essential for promoting the effective management of groundwater resources. The water quality index is understood to be one of the utmost efficient tools for communicating information regarding a water body class, people engaged in making policy, and involved residents (Patel et al. 2020). A mathematical equation is utilized to convert data on water quality to a single number (Zotou et al. 2020; Karnena and Saritha 2019; Verma et al. 2020). The dawn of technologies, including satellites and GIS (geographical information system), enabled easy mapping of the sampling sites and generated user-friendly and informative maps precisely for understanding the quality of water (Facchinelli et al. 2001; Zhang et al. 2020; Sinha et al. 2021). The focus of the present work was to determine the quality of water, which was carried out employing the method of weighted arithmetic index proposed by (Jha et al. 2020; Tharani and Abhilash 2021), wherein ten essential characteristics, including physical parameters like $\mathrm{pH}$, total dissolved solids and chemical characteristics including magnesium, calcium, fluoride, chlorides, sulphates, nitrates, potassium and sodium were considered for assessment.

\section{Methodology}

\section{Collection of sample and analysis of physicochemical parameters}

Groundwater quality of Srikakulam District was analysed prior and past-rainfall seasons during 2016-2017; water samples were collected from bores varying depths of 25 to 100 m. Thirty-eight Mandal Head Quarters of Srikakulam District in A.P were included from where samples were collected for analysis carried out at Environmental science laboratory of GITAM Institute of Science, GITAM (Deemed to be University), and Visakhapatnam using standard methods given by APHA.

\section{Sampling stations and samples}

Area of study along with sampling stations is shown in Fig. 1 and is listed in Table 1. Water samples from 152 subsurface sources were grabbed from the 38 sites and were subjected to analysis during 2016 and 2017, prior to and past-rainfall season seasons.

\section{Parameters selected for potability studies}

For potability studies in relation to standards laid by BIS, the collected samples were subjected to analysis for ten crucial quality parameters, including physical and chemical characterization. Physical characteristics studied were $\mathrm{pH}$, Solids in terms of total dissolved solids, while chemical 


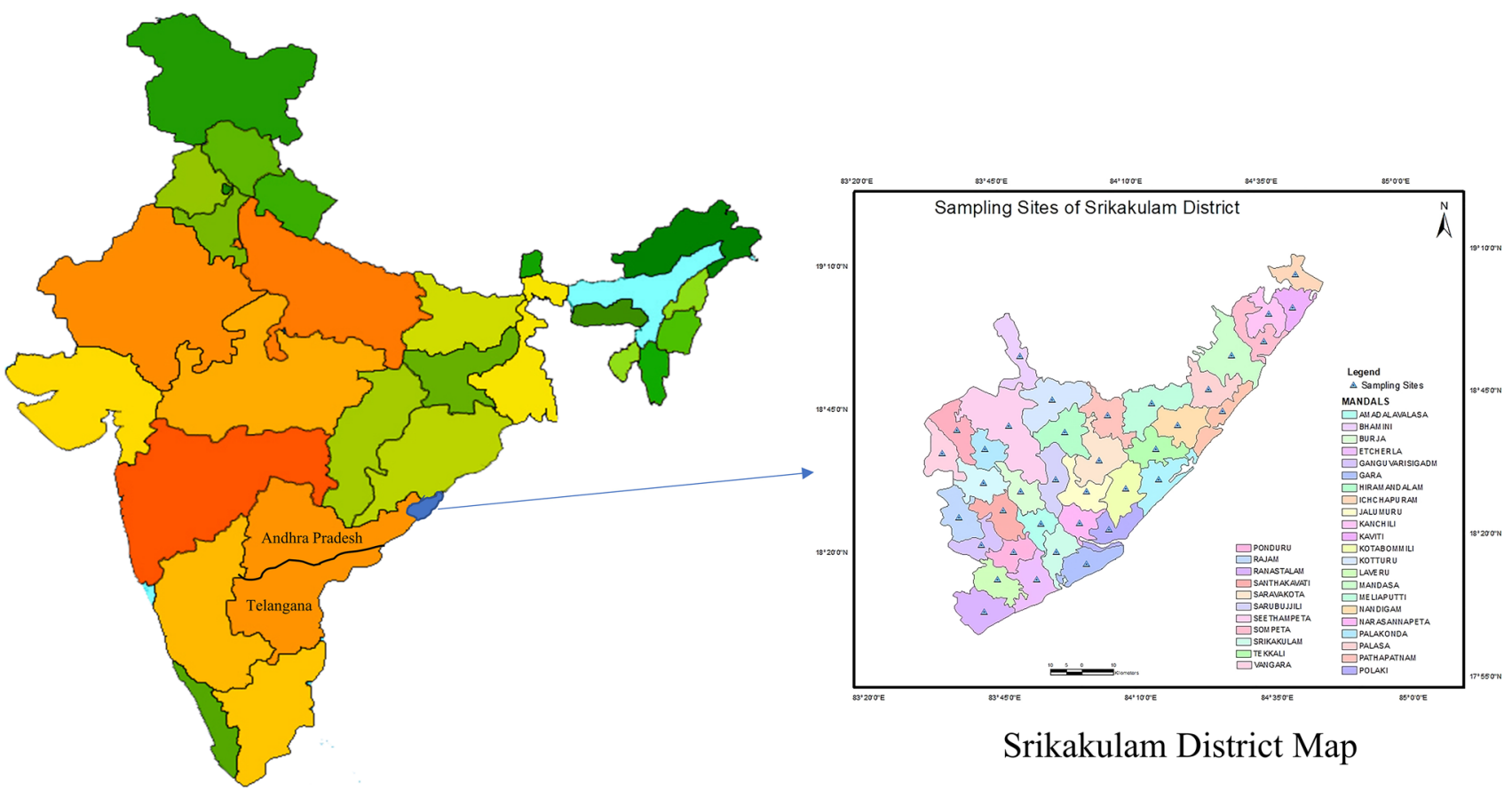

India Map

Fig. 1 Location map presenting study area

Table 1 Latitude and Longitude of selected sampling zones in Srikakulam district

\begin{tabular}{|c|c|c|c|c|c|c|c|}
\hline \multirow[t]{2}{*}{ S. No (S) } & \multirow[t]{2}{*}{ Station } & \multicolumn{2}{|c|}{ Samples collected } & \multirow[t]{2}{*}{ S. No (S) } & \multirow[t]{2}{*}{ Station } & \multicolumn{2}{|c|}{ Samples collected } \\
\hline & & Lat & Long & & & Lat & long \\
\hline 1 & Amadalavalasa & $18^{0} 24^{\prime} 53^{\prime \prime}$ & $83^{0} 53^{\prime} 57^{\prime \prime}$ & 20 & Palakonda & $18^{0} 36^{\prime} 13^{\prime \prime}$ & $83^{0} 45^{\prime} 22^{\prime \prime}$ \\
\hline 2 & Bhamini & $18^{0} 54^{\prime} 36^{\prime \prime}$ & $83^{0} 49^{\prime} 11^{\prime \prime}$ & 21 & Palasa & $18^{0} 46^{\prime} 19^{\prime \prime}$ & $85^{0} 24^{\prime} 35^{\prime \prime}$ \\
\hline 3 & Burja & $18^{0} 31^{\prime} 06^{\prime \prime}$ & $83^{0} 48^{\prime} 9^{\prime \prime}$ & 22 & Pathapatnam & $18^{0} 44^{\prime} 53^{\prime \prime}$ & $84^{0} 05^{\prime} 18^{\prime \prime}$ \\
\hline 4 & Etcherla & $18^{0} 16^{\prime} 54^{\prime \prime}$ & $83^{0} 49^{\prime} 28^{\prime \prime}$ & 23 & Polaki & $18^{0} 22^{\prime} 35^{\prime \prime}$ & $84^{0} 06^{\prime} 03^{\prime \prime}$ \\
\hline 5 & Ganguvarisigadam & $18^{0} 22^{\prime} 54^{\prime \prime}$ & $83^{0} 40^{\prime} 53^{\prime \prime}$ & 24 & Ponduru & $18^{0} 20^{\prime} 59^{\prime \prime}$ & $83^{0} 45^{\prime} 26^{\prime \prime}$ \\
\hline 6 & Gara & $18^{0} 19^{\prime} 52^{\prime \prime}$ & $84^{0} 30^{\prime} 28^{\prime \prime}$ & 25 & Rajam & $18^{0} 27^{\prime} 20^{\prime \prime}$ & $83^{0} 38^{\prime} 54^{\prime \prime}$ \\
\hline 7 & Hiramandalam & $18^{0} 40^{\prime} 17^{\prime \prime}$ & $83^{0} 57^{\prime} 01^{\prime \prime}$ & 26 & Ranastalam & $18^{0} 12^{\prime} 07^{\prime \prime}$ & $83^{0} 41^{\prime} 23^{\prime \prime}$ \\
\hline 8 & Ichchapuram & $19^{0} 06^{\prime} 53^{\prime \prime}$ & $84^{0} 41^{\prime} 09^{\prime \prime}$ & 27 & R.Amadalavalasa & $18^{0} 33^{\prime} 03^{\prime \prime}$ & $83^{0} 44^{\prime} 21^{\prime \prime}$ \\
\hline 9 & Jalumuru & $18^{0} 30^{\prime} 41^{\prime \prime}$ & $84^{0} 02^{\prime} 15^{\prime \prime}$ & 28 & Santhabommali & $18^{0} 32^{\prime} 10^{\prime \prime}$ & $84^{0} 12^{\prime} 29^{\prime \prime}$ \\
\hline 10 & Kanchili & $18^{0} 58^{\prime} 50^{\prime \prime}$ & $84^{0} 34^{\prime} 55^{\prime \prime}$ & 29 & Santhakaviti & $18^{0} 27^{\prime} 28^{\prime \prime}$ & $83^{0} 46^{\prime} 50^{\prime \prime}$ \\
\hline 11 & Kaviti & $19^{0} 00^{\prime} 41^{\prime \prime}$ & $84^{0} 41^{\prime} 23^{\prime \prime}$ & 30 & Saravakota & $18^{0} 35^{\prime} 31^{\prime \prime}$ & $84^{0} 03^{\prime} 07^{\prime \prime}$ \\
\hline 12 & Kotabommali & $18^{0} 31^{\prime} 04^{\prime \prime}$ & $84^{0} 09^{\prime} 05^{\prime \prime}$ & 31 & Sarubujjili & $18^{0} 31^{\prime} 13^{\prime \prime}$ & $83^{0} 53^{\prime} 36^{\prime \prime}$ \\
\hline 13 & Kothuru & $18^{0} 46^{\prime} 43^{\prime \prime}$ & $83^{0} 52^{\prime} 53^{\prime \prime}$ & 32 & Seethampeta & $18^{0} 41^{\prime} 33^{\prime \prime}$ & $83^{0} 48^{\prime} 53^{\prime \prime}$ \\
\hline 14 & Lakshminarsupeta & $18^{0} 25^{\prime} 06^{\prime \prime}$ & $84^{0} 02^{\prime} 23^{\prime \prime}$ & 33 & Sompeta & $18^{0} 56^{\prime} 45^{\prime \prime}$ & $85^{0} 35^{\prime} 03^{\prime \prime}$ \\
\hline 15 & Laveru & $18^{0} 14^{\prime} 16^{\prime \prime}$ & $83^{0} 41^{\prime} 48^{\prime \prime}$ & 34 & Srikakulam & $18^{0} 17^{\prime} 47^{\prime \prime}$ & $83^{0} 53^{\prime} 04^{\prime \prime}$ \\
\hline 16 & Mandasa & $18^{0} 52^{\prime} 11^{\prime \prime}$ & $84^{0} 27^{\prime} 30^{\prime \prime}$ & 35 & Tekkali & $18^{0} 36^{\prime} 19^{\prime \prime}$ & $84^{0} 13^{\prime} 49^{\prime \prime}$ \\
\hline 17 & Meliaputti & $18^{0} 46^{\prime} 28^{\prime \prime}$ & $84^{0} 10^{\prime} 23^{\prime \prime}$ & 36 & Vajrapukothuru & $18^{0} 42^{\prime} 03^{\prime \prime}$ & $84^{0} 26^{\prime} 00^{\prime \prime}$ \\
\hline 18 & Nandigam & $18^{0} 21^{\prime} 55^{\prime \prime}$ & $84^{0} 08^{\prime} 32^{\prime \prime}$ & 37 & Vangara & $18^{0} 37^{\prime} 04^{\prime \prime}$ & $83^{0} 36^{\prime} 28^{\prime \prime}$ \\
\hline 19 & Narasannape & $18^{0} 24^{\prime} 56^{\prime \prime}$ & $84^{0} 02^{\prime} 41^{\prime \prime}$ & 38 & Veeraghattam & $18^{0} 41^{\prime} 18^{\prime \prime}$ & $83^{0} 36^{\prime} 30^{\prime \prime}$ \\
\hline
\end{tabular}


characteristics evaluated comprised of total hardness including calcium and magnesium, fluoride, chlorides, nitrates, sulphates, potassium and sodium. Analysis followed standard protocols laid by APHA, 2015.

\section{Given below is the methodology applied towards calculating WQI}

a. Weightage factor For calculation, first, the weightage of the individual parameter is calculated. Weightage for different characteristics is allocated which is contrarywise relational to suggested standards for interrelated parameters. Therefore,

Wi $\infty 1 / \mathrm{Si}$

$\mathrm{Wi}=K / \mathrm{Si}$

b. Water quality rating The calculation of rating is based on the equation given below, where $V_{a}$ and $V_{i}$ correspond to real and perfect values of water quality. Further, for all parameters, the perfect value is 0 excluding $\mathrm{pH}$ and dissolved oxygen.

$q_{i}=\left\{\left[\left(V_{a}-V_{i}\right) /\left(S_{i}-V_{i}\right)\right]^{*} 100\right\}$

c. Calculation Principally, WQI is an assembly of several parameters which can be employed to assess complete water quality (Table 2). Parameters included in WQI are $\mathrm{pH}$, chlorides, calcium, sodium, potassium, magnesium, fluorides, nitrates, sulphates, and total dissolved solids. The numerical value pertaining to rating of the quality is then multiplied by a weightage factor (Table 3) relates to the test's significance of water quality. Sum of the values that result are then added towards arriving at a complete water quality index.

d. Water quality index WQI $=\Sigma$ qiwi (Water quality rating)

$q_{i}=\left\{\left[\left(V_{a}-V_{i}\right) /\left(S_{i}-V_{i}\right)\right]^{*} 100\right\}$

$v_{a}=$ actual value present in the water sample.

$v_{i}=$ ideal value ( 0 for all parameters except $\mathrm{PH}$ and $\mathrm{DO}$ ). $\mathrm{Wi}=K / \mathrm{Si}$.

Table 2 Water Quality Scale concerning WQI

\begin{tabular}{ll}
\hline Quality of water & $\begin{array}{l}\text { Water quality } \\
\text { index (WQI) }\end{array}$ \\
\hline Exceptional & 0 to 24 \\
Good quality & 25 to 50 \\
Inferior & 50 to 75 \\
Bad & 75 to 100 \\
Not fit for drinking & $>100$ \\
\hline
\end{tabular}

Table 3 Component wise weightage of characteristics as per BIS

\begin{tabular}{lll}
\hline Characteristic & $\begin{array}{l}\text { Standard value }(\mathrm{Sn} \\
\& \mathrm{Si})\end{array}$ & $\begin{array}{l}\text { Assigned } \\
\text { weightage factor } \\
(\mathrm{Wi})\end{array}$ \\
\hline $\mathrm{pH}$ & 8.5 & 0.1363529 \\
Calcium & 75 & 0.0154533 \\
Chlorides & 250 & 0.0046360 \\
Fluorides & 1.5 & 0.7726666 \\
Magnesium & 30 & 0.0386333 \\
Nitrates & 45 & 0.0257555 \\
Total Dissolved Solids & 500 & 0.00231800 \\
Sulphates & 250 & 0.004 \\
Sodium & 200 & 0.005 \\
Potassium & 10 & 0.1 \\
\hline
\end{tabular}

*All values except for $\mathrm{pH}$ are expressed in $\mathrm{mg} / \mathrm{l}$

Where wi (unit weight).

$k$ (constant $)=1 /\left(1 / V_{s 1}+1 / V_{s 2}+\cdots+1 / V_{s n}\right) ; \mathrm{Sn}=$ standard value.

\section{Water quality indices}

Since their formulation, water quality indices were developed by several researchers over time and adopted for various studies. These are understood to be an efficient tool for converting an extensive set of data into a precise, informative, and meaningful form to extract characteristics of the sample's underlying facts. Weighted Arithmetic Index has been implemented to assess existing water quality status and identify those physicochemical parameters that cause pollution. The present study adopted the WQI given by (Verma et al. 2020; Zhang et al. 2020; Karnena and Saritha 2019; Jha et al. 2020).

\section{Statistical methods}

Values of Correlation coefficient (r) were found out employing the correlation matrix for identification of greatly interrelated, correlated parameters of water quality.

\section{Results and discussion}

Srikakulam District is situated within $18.6177^{\circ} \mathrm{N}$ and $84.0167^{\circ} \mathrm{E}$ of Northern latitude and $83^{\circ}-50^{\prime}$ and $84^{\circ}-50^{\prime}$ of Eastern longitude. Srikakulam is the second-most backward district in Andhra Pradesh, India. The community has an industry called Dr. Reddy's Laboratories at Pydibhimavaram. The district has a lot of scope for development in the future with the forthcoming establishment of a thermal power plant at Sompeta and a nuclear power plant at 
Ranasthalam. The district is bordered to a distance by Vamsadhara, Kandivalasagedda, and Bahuda at specific spans of their courses white a line of elevations of the great Eastern Ghats that run from North-East. The study is undertaken for thirty-eight sampling stations throughout the Srikakulam District. Groundwater suitability at diverse locations from study area for consumption and irrigation was evaluated.

\section{Potability studies (as per BIS)}

The present study assessed groundwater potability based on analysis of physicochemical parameters and assessment of groundwater quality indices.

\section{Physicochemical analysis}

Based on the physicochemical analysis, the estimation of groundwater quality for its appropriateness towards consumption is one of the present study's objectives. The graphs and thematic maps below illustrate the result of analysis of samples collected prior to and past-rainfall season seasons of 2016 and 2017. In the study period, the temporal and spatial disparity in each water quality was presented.

Seasonal variation for the year 2016 and 2017 Seasonal variations of the groundwater's physicochemical characteristics by comparing prior to and past-rainfall season data in the area of study for 2016 and 2017 are as follows.

a) $\boldsymbol{p H}$ : During 2016, 6.5 to 8.8 of $\mathrm{pH}$ was noted prior to-rainfall season, while past-rainfall season recorded 7.2 to 8.9. The comparison of $\mathrm{pH}$ between prior to and past-rainfall season was plotted in the graph as shown in Fig. 2a. An alkaline nature was illustrated by maximum samples from the study. In prior to-rainfall season, $58 \%$ of the sample station's $\mathrm{pH}$ values are more than the highest desirable level (6.5-8.5) during both the years. The $\mathrm{pH}$ range is between 7.34 and 8.93 for prior to-rainfall season and 7.58 and 8.69 for past-rainfall season during 2017.

The thematic maps have been generated by ARC GIS 10.3 software using a spatial analysis tool. The classification of water quality parameter $\mathrm{pH}$ is alienated into three categories according to BIS. These are suitable for drinking (6.5 to 8.5) and not ideal for drinking (less than 6.5 and more significant than 8.5). Figures $3 \mathrm{a}$ and $\mathrm{b}$ and $4 \mathrm{a}$ and $\mathrm{b}$ present the spatial distribution of water quality parameter $\mathrm{pH}$.

b) Total dissolved solids (TDS): For 2016, 79.36 to $2112 \mathrm{mg} / \mathrm{l}$ of TDS was recorded during prior to-rainfall season, and 118.02 to $1296 \mathrm{mg} / \mathrm{l}$ was observed in the past-rainfall season, indicating maximum sampling sites in the study falling above standard level. Thus, it can be understood that agricultural activity was the chief anthropogenic impact leading to disparity in spatial and temporal run-off of the location. Figure $2 \mathrm{~b}$ shows the total dissolved solids graph compared between prior to and past-rainfall season. During 2017, 70.4 to $3584 \mathrm{mg} / \mathrm{l}$ of TDS was reported during prior torainfall season and 134.4 to $3392 \mathrm{mg} / \mathrm{l}$ for past-rainfall season, indicating that maximum sampling sites fall above standard levels.

These are most suitable for less than desirable value for drinking $(<500 \mathrm{mg} / \mathrm{l})$ and allowable for consumption (in between 500 and $1500 \mathrm{mg} / \mathrm{l}$ ). Figures $3 \mathrm{c}$ and $\mathrm{d}$ and $4 \mathrm{c}$ and $\mathrm{d}$ show the spatial distribution of TDS during both prior to and past-rainfall season.

c) Chlorides: The chloride value was in the range of 20 to $471 \mathrm{mg} / \mathrm{l}$ in prior to-rainfall season, and 30 to $500 \mathrm{mg} / \mathrm{l}$ in past-rainfall season was observed during 2016. Figure $2 \mathrm{c}$ shows the fluoride graph compared between prior to and past-rainfall season. The concentration of chloride in most of the samples was more significant than the highest desirable level (250 mg/l). For 2017, the chloride value ranged from 14.184 to $496.44 \mathrm{mg} / \mathrm{l}$ for prior to-rainfall season, and 30 to $1360 \mathrm{mg} / \mathrm{l}$ for past-rainfall season was observed. The chloride concentration in most of the samples was more significant than the maximum enticing level (250 mg/l) prescribed by BIS.

Nevertheless, values from the study are found to be entirely lower than maximum permissible limit (1000 $\mathrm{mg} / \mathrm{l})$. Anthropogenic sources of chloride are from bleaching agents by communities nearby bore well and septic tank effluents. The classification of water quality parameter chloride is alienated into three categories according to BIS. These are most suitable for drinking $(<250 \mathrm{mg} / \mathrm{l})$ and not ideal for drinking (in between 250 and $600 \mathrm{mg} / \mathrm{l}$ and greater than $600 \mathrm{mg} / \mathrm{l}$ ). Figures $3 \mathrm{e}$ and $\mathrm{f}$ and $4 \mathrm{e}$ and $\mathrm{f}$ show the spatial distribution of water quality parameter chlorides in both prior to and past-rainfall season.

d) Fluorides: During 2016, subsurface water generally contains fluoride, which is dissolved from the geological formation. Figure $2 \mathrm{~d}$ shows the fluoride graph compared between prior to and past-rainfall season. The concentration of Fluoride in sampling stations ranged between 0.01 and $1.2 \mathrm{mg} / \mathrm{l}$ in prior to-rainfall season and 0.1 and $1.3 \mathrm{mg} / \mathrm{l}$ in past-rainfall season seasons. Enhanced fluoride concentrations might lead to deformities like dental and skeletal fluorosis. For 2017, concentration of Fluoride ranged between 0.02 and $0.88 \mathrm{mg} / \mathrm{l}$ in prior to-rainfall season and 0.02 and $0.89 \mathrm{mg} / \mathrm{l}$ in past rainfall season seasons. The classification of water quality parameter fluoride is alienated into three categories. These are most suitable for less than desirable value for drinking $(<1 \mathrm{mg} / \mathrm{l})$ and not suitable for drinking (in between 1 and $1.5 \mathrm{mg} / \mathrm{l}$ and more significant than $1.5 \mathrm{mg} / \mathrm{l})$. Fig- 


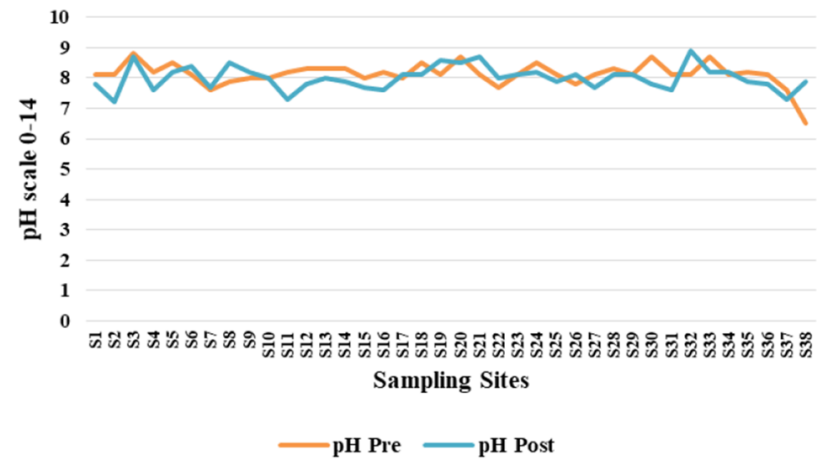

2016

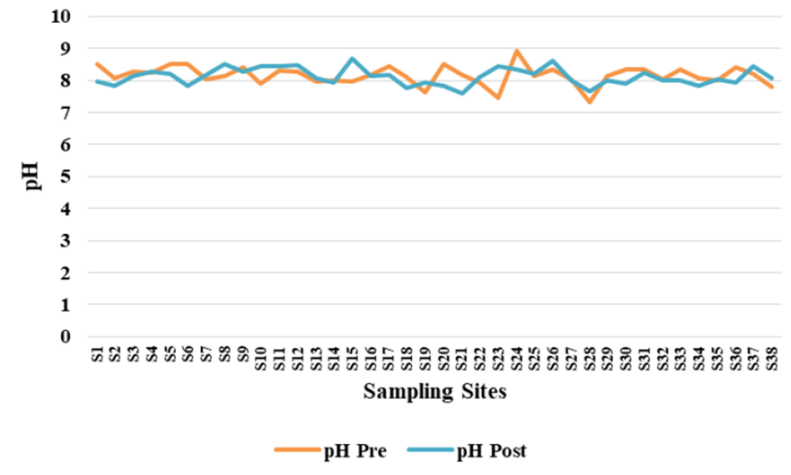

2017

(a) $\mathrm{pH}$ comparison in prior to and past rainfall season.

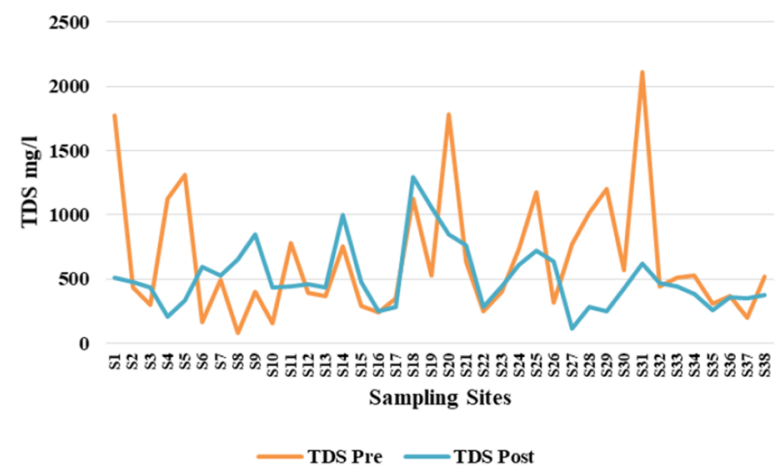

2016

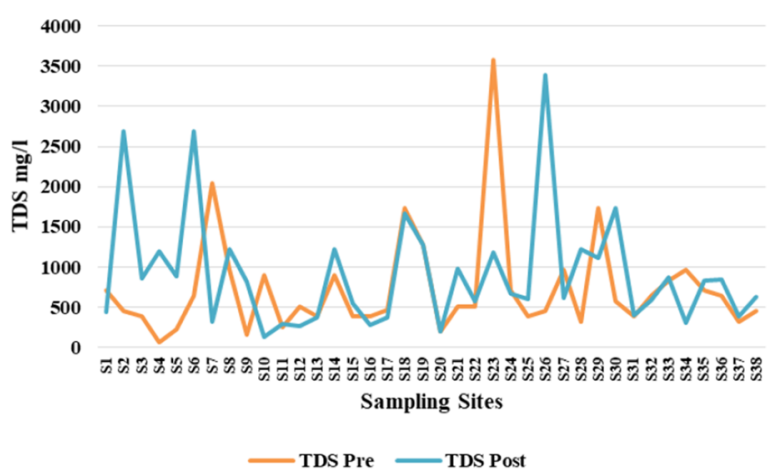

2017

(b) Comparison of TDS prior to and past rainfall season.

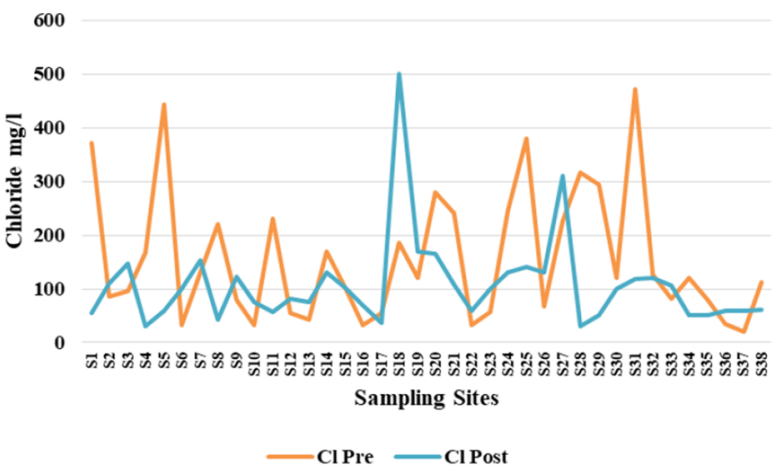

2016

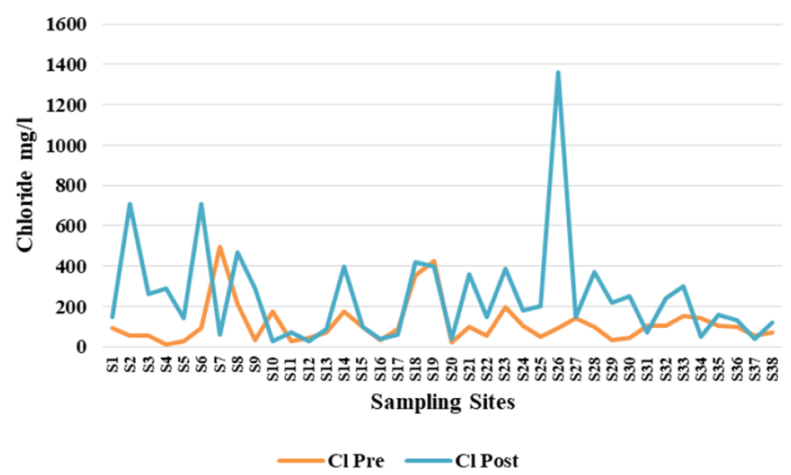

2017

(c) Concentration of chloride prior to and past rainfall season.

Fig. 2 Depicts the comparisons of elemental concentrations of pre- and post-monsoon 


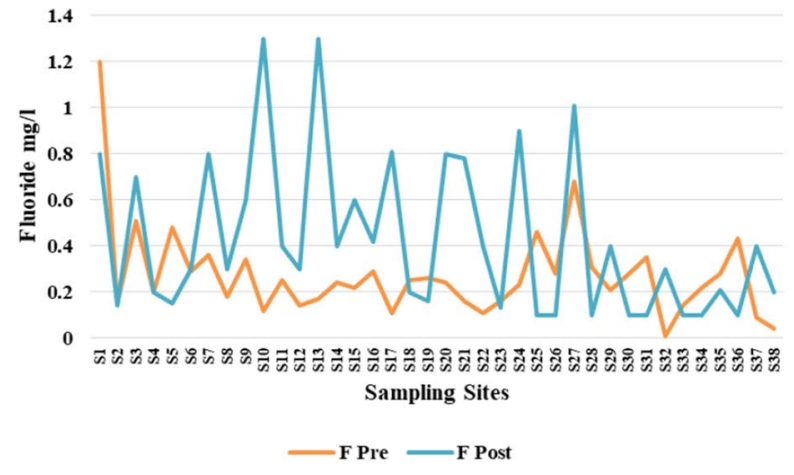

2016

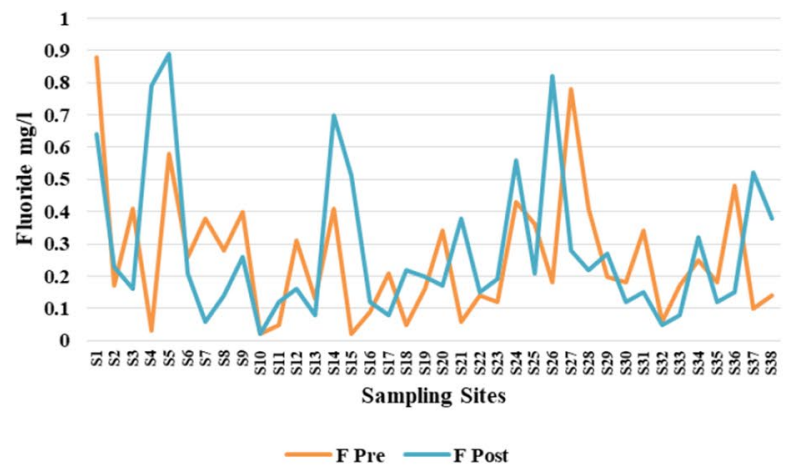

2017

(d) Comparison of fluoride concentration in prior to and past rainfall season.

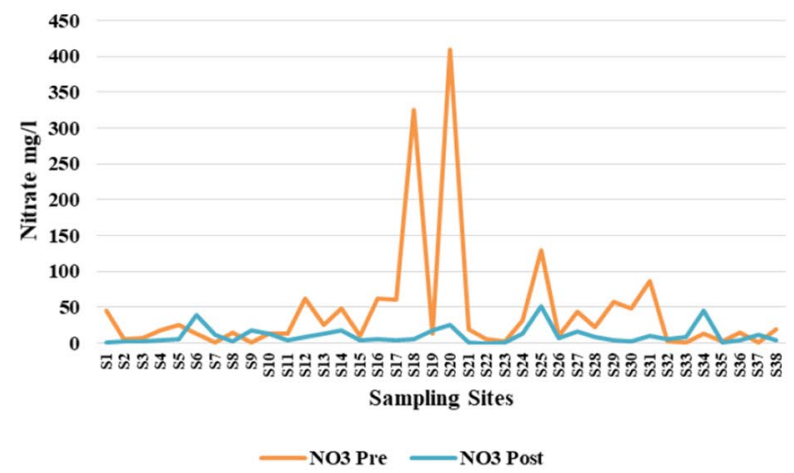

2016

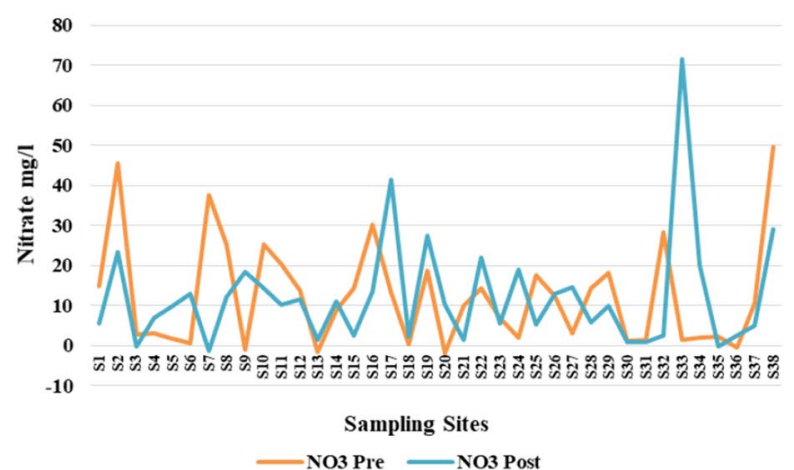

2017

(e) Comparison of nitrates concentration in prior to and past rainfall season

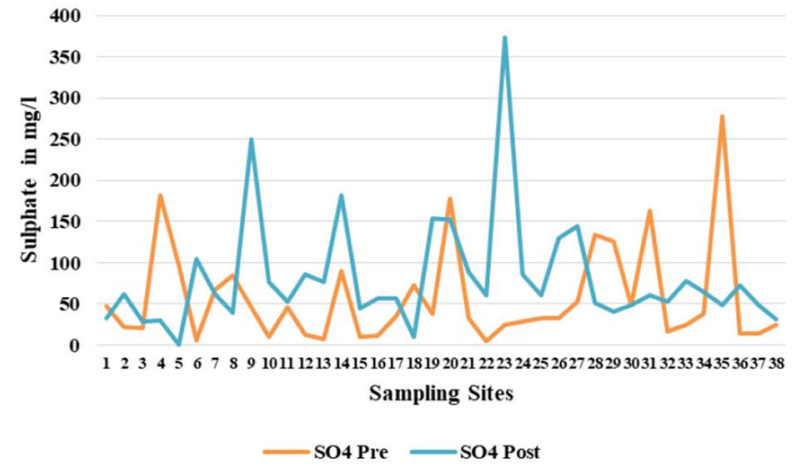

2016

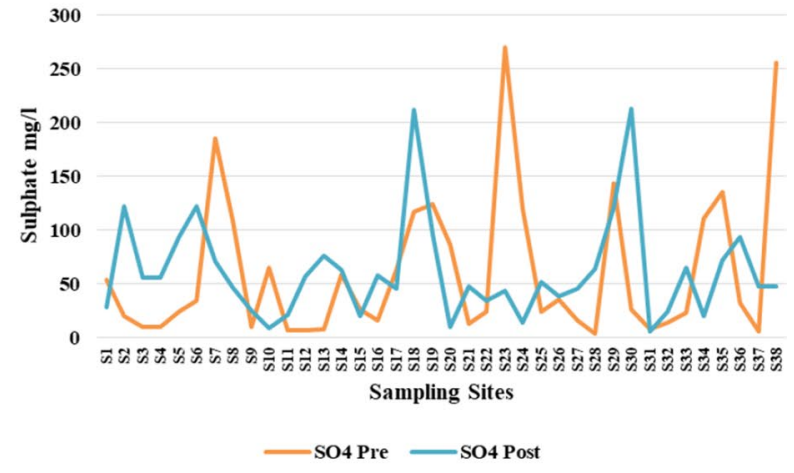

2017

(f) Concentration of sulphates prior to and past rainfall season

Fig. 2 (continued) 

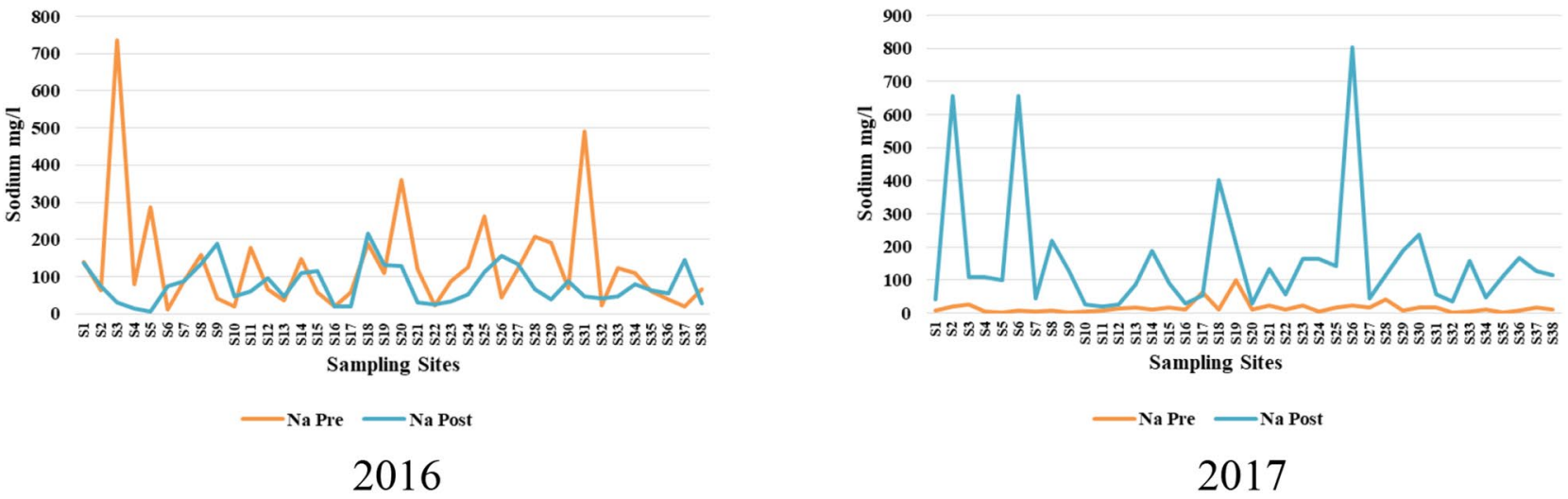

(g) Comparison of sodium amount in prior to and past rainfall season
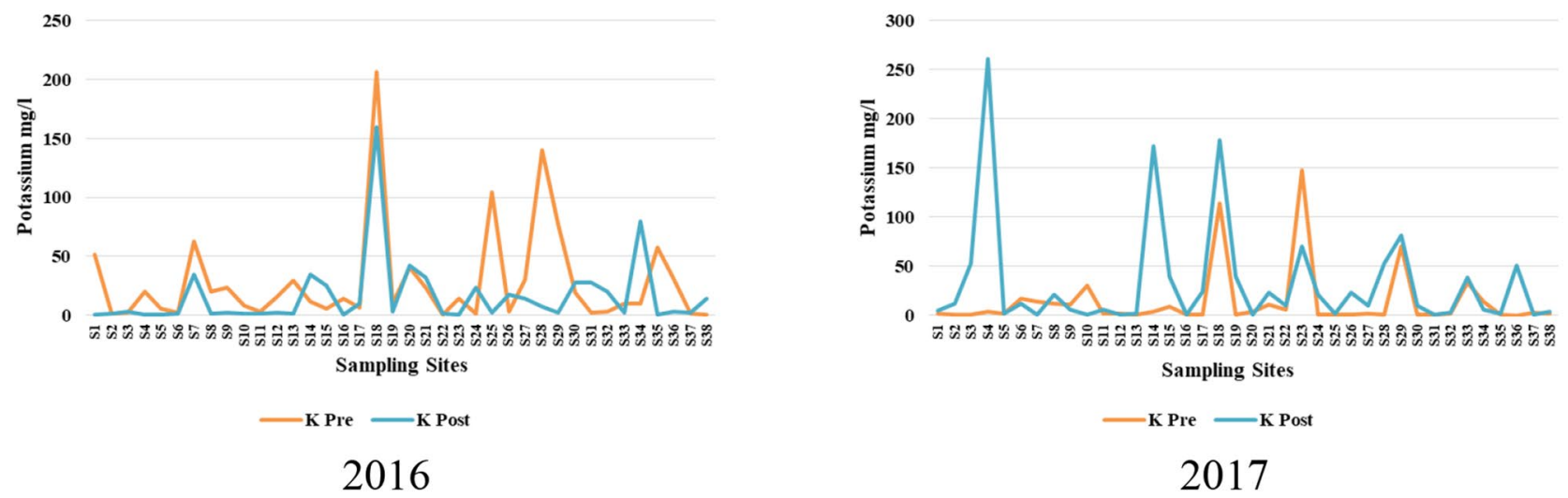

(h) Concentration of potassium prior to and past rainfall season.

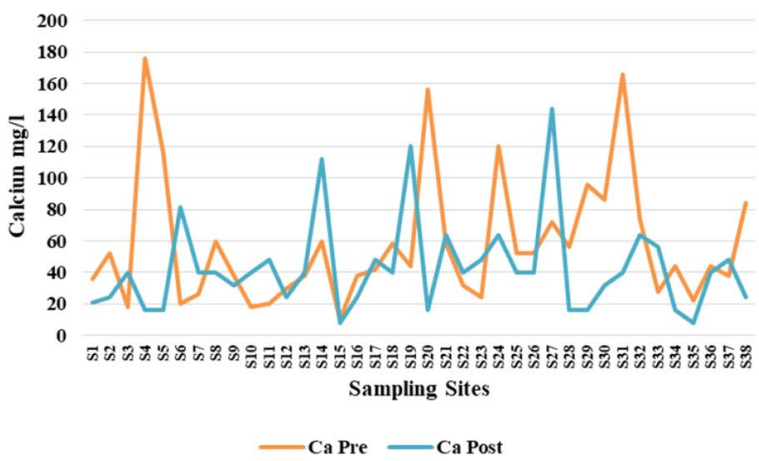

2016

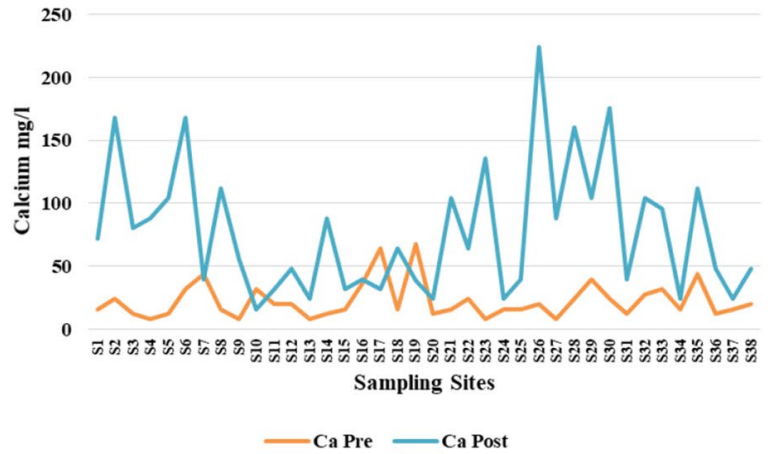

2017

(i) Comparison of calcium concentration in prior to and past rainfall season.

Fig. 2 (continued) 


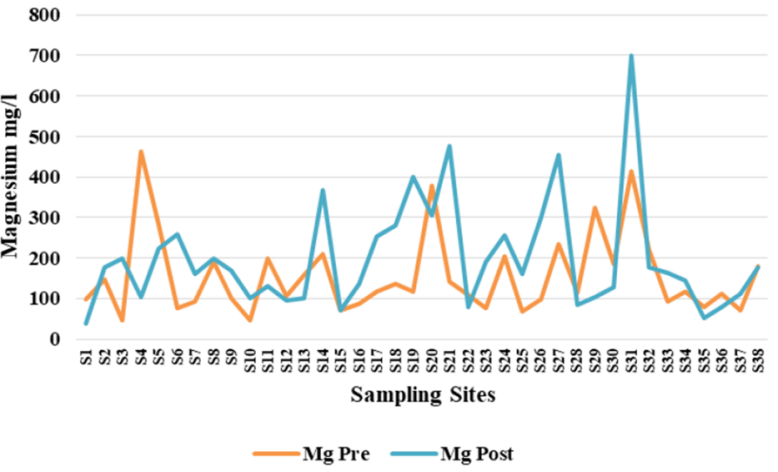

2016

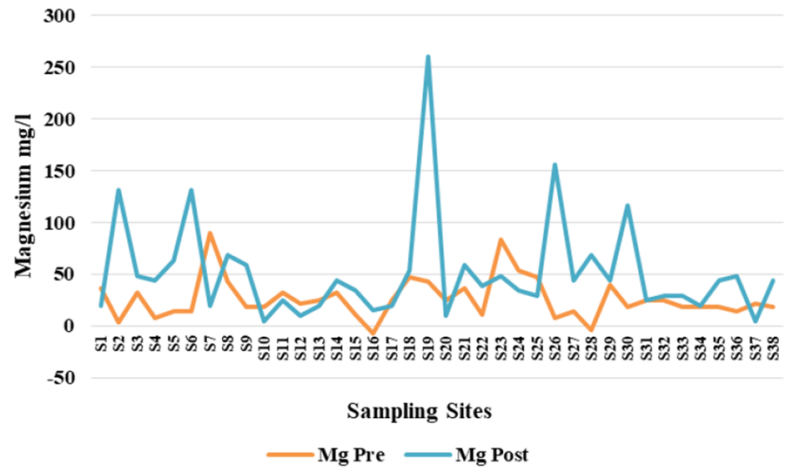

2017

(j) Concentration of magnesium prior to and past rainfall season.

Fig. 2 (continued)

ure 3 ( $\mathrm{g}$ and $\mathrm{h}$ ) and Fig. 4 ( $\mathrm{g}$ and $\mathrm{h}$ ) show the spatial distribution of water quality parameter fluorides in both prior to and past-rainfall season.

e) Nitrates: During 2016, nitrates levels from current study stations ranged from 0.62 to $409.2 \mathrm{mg} / \mathrm{l}$ during prior to-rainfall season, while 0.03 to $51 \mathrm{mg} / \mathrm{l}$ for the past-rainfall season. Figure 2e shows a graph plotted for the comparison of prior to and past-rainfall season for nitrates. Maximum stations are in the enticing limit of $45 \mathrm{mg} / \mathrm{l}$-nitrate levels, since more than $45 \mathrm{mg} / \mathrm{l}$ causes Methemoglobinemia in infants. For 2017, the present study's nitrate levels ranged from -1.82 to $49.6 \mathrm{mg} / \mathrm{l}$ in the prior to-rainfall season and -1.45 to $71.45 \mathrm{mg} / \mathrm{l}$ in the past-rainfall season. Most sampling sites fall well in the enticing limit of $45 \mathrm{mg} / \mathrm{l}$.

Classification of nitrates is alienated into three categories according to BIS. These are most suitable for less than desirable value for drinking $(<45 \mathrm{mg} / \mathrm{l})$ and unsuitable for drinking is greater than $45 \mathrm{mg} / \mathrm{l}$. Figures $3 i$ and $\mathrm{j}$ and $4 \mathrm{i}$ and $\mathrm{j}$ show the spatial distribution of nitrates in both prior to and past rainfall season.

f) Sulphates: During 2016, sulphate concentrations in the sampling sites ranged from 5 to $278 \mathrm{mg} / \mathrm{l}$ for prior to-rainfall season and 0.82 to $374 \mathrm{mg} / \mathrm{l}$ for past-rainfall season. Figure $2 \mathrm{f}$ shows a graph plotted for the sulphate's comparison between the prior to and past-rainfall season. For 2017, sulphate concentrations from sampling sites ranged from 4 to $270 \mathrm{mg} / \mathrm{l}$ in prior to-rainfall season and 6 to $213 \mathrm{mg} / \mathrm{l}$ in past-rainfall season, respectively. The classification of water quality parameter sulphates is alienated into two categories according to BIS. These are suitable for drinking $(<250 \mathrm{mg} / \mathrm{l})$. Figures $3 \mathrm{k}$ and 1 and $4 \mathrm{k}$ and 1 show the spatial distribution of calcium in both prior to and past-rainfall season. g) Sodium: During 2016, sodium concentration in sampling sites ranged from 12.19 to $736 \mathrm{mg} / \mathrm{l}$ in prior torainfall season and 6.9 to $215 \mathrm{mg} / \mathrm{l}$ in past-rainfall season, respectively. Figure $2 \mathrm{~g}$ shows a graph plotted for the sodium comparison between the prior to and past-rainfall season. For 2017, sodium concentration in sampling sites extended from 0.78 to $98.8 \mathrm{mg} / \mathrm{l}$ in prior to-rainfall season and 19.1 to $804.2 \mathrm{mg} / \mathrm{l}$ in past-rainfall season, respectively. The classification of water quality parameter sodium is alienated into two categories according to BIS. These are suitable for drinking $(<20 \mathrm{mg} / \mathrm{l})$ and not ideal for drinking ( $>200 \mathrm{mg} / \mathrm{l}$ ). Figure $3 \mathrm{~m}$ and $\mathrm{n}$ and $4 \mathrm{~m}$ and $\mathrm{n}$ show the spatial distribution of water quality parameter calcium in both prior to and past-rainfall season.

h) Potassium: During 2016, potassium concentration in sampling sites ranging from 0.69 to $206.7 \mathrm{mg} / \mathrm{l}$ in prior to-rainfall season and 0.39 to $160 \mathrm{mg} / \mathrm{l}$ in past-rainfall season, respectively. Figures $2 \mathrm{~h}$ shows a graph plotted for the potassium comparison between the prior to and past-rainfall season. For 2017, amount of potassium in sampling sites ranged from 0.3 to $147.8 \mathrm{mg} / \mathrm{l}$ in prior to rainfall season and 0.53 to $260.9 \mathrm{mg} / \mathrm{l}$ in past rainfall season. The classification of water quality parameter potassium is alienated into three categories according to BIS. These are suitable for drinking $(<100 \mathrm{mg} / \mathrm{l})$ and not fit for consumption ( $>200 \mathrm{mg} / \mathrm{l}$ ), and not acceptable ( $>500 \mathrm{mg} / \mathrm{l}$ ). Figure $3 \mathrm{o}$ and $\mathrm{p}$ and $4 \mathrm{o}$ and $\mathrm{p}$ show the spatial distribution of calcium in both prior to and pastrainfall season.

i) Calcium: During 2016, calcium concentrations among the sampling stations ranged between 10 and $172 \mathrm{mg} / \mathrm{l}$ for prior to-rainfall season and 8 and $144 \mathrm{mg} / \mathrm{l}$ for pastrainfall season. In some of the stations, the concentrations fell above the prescribed standard of $75 \mathrm{mg} / \mathrm{l}$ dur- 


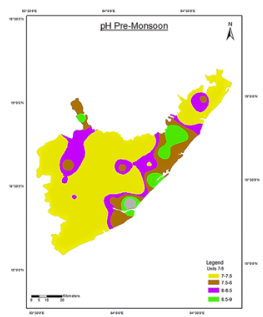

(a)

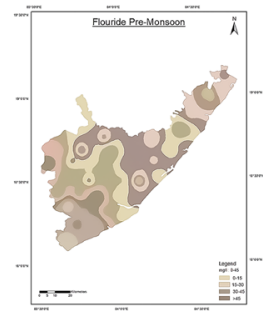

(g)

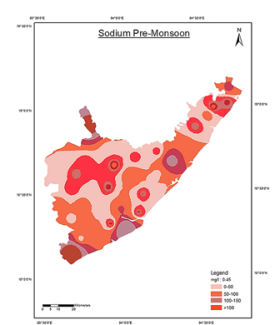

(m)

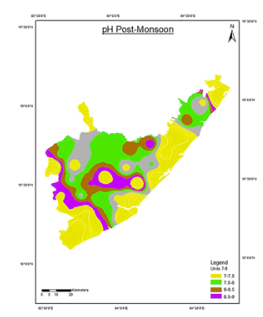

(b)

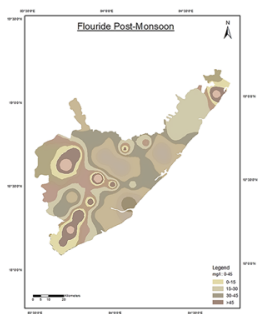

(h)

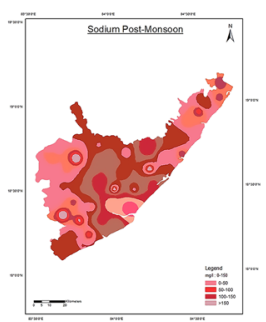

(n)

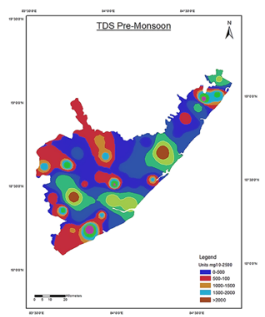

(c)

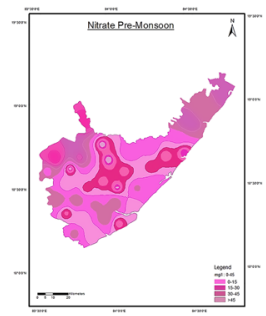

(i)

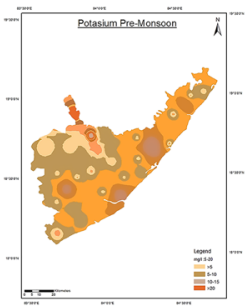

(o)

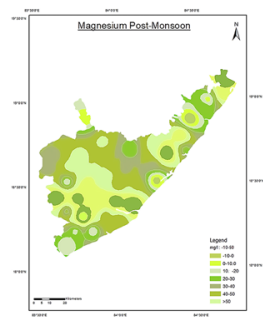

(s)

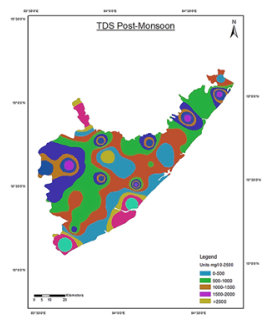

(d)

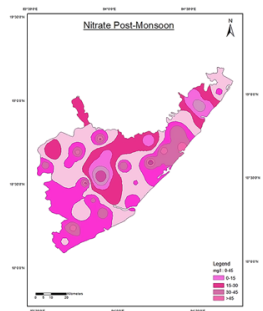

(j)

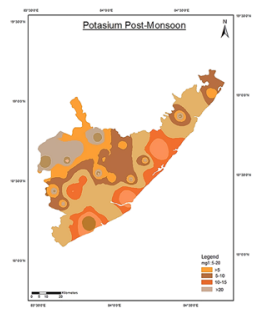

(p)

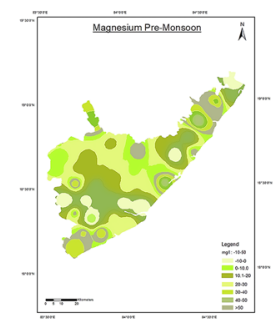

(t)

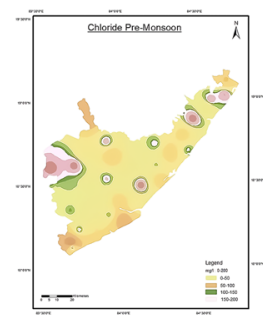

(e)

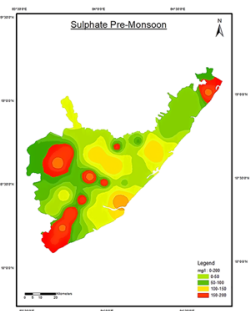

(k)

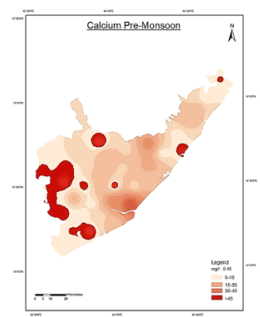

(q)

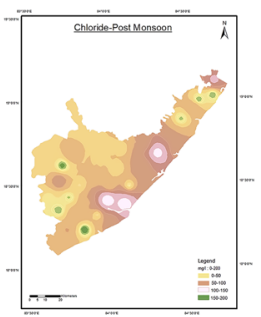

(f)

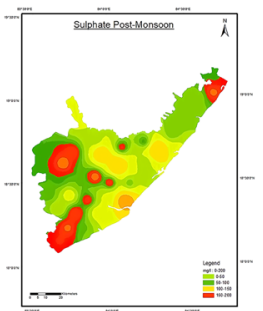

(l)

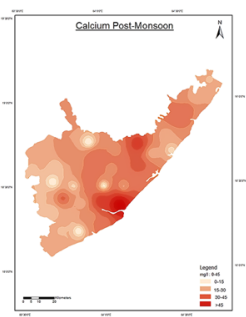

(r)

Fig. 3 Thematic maps of the different elements of pre- and post-monsoon of 2016

ing both the years. Figure $2 \mathrm{i}$ shows a graph plotted for the calcium presents comparison among the prior to and past-rainfall season. The enhanced values are owed to the abundant availability of limestone in the location resulting in enhanced solubility of calcium ions. For 2017 , amount of calcium from current study area ranged between 8 and $68 \mathrm{mg} / \mathrm{l}$ for prior to-rainfall season and 16 and $224 \mathrm{mg} / \mathrm{l}$ for past-rainfall season. Classification of calcium is alienated into three categories according to BIS. These are suitable for drinking $(<75)$ and not ideal for drinking (75-200 and $>200)$. Figures $3 q$ and $r$ and $4 \mathrm{q}$ and $\mathrm{r}$ show the spatial distribution of calcium in both prior to and past-rainfall season.

j) Magnesium: During 2016, magnesium in the current study ranged from 47 to $464 \mathrm{mg} / \mathrm{l}$ in the pre-rainfall season and 39 to $700 \mathrm{mg} / \mathrm{l}$ in the past-rainfall season. Magnesium falls above the standard limit in some of the sampling stations for both seasons. The magnesium concentration may be very high credited to the dissolution of magnesium, gypsum, dolomite and calcite. Figure $2 \mathrm{j}$ shows a graph plotted for the magnesium comparison between the prior to and past-rainfall season. For 2017 , magnesium in sampling sites ranged from -7.2 to 


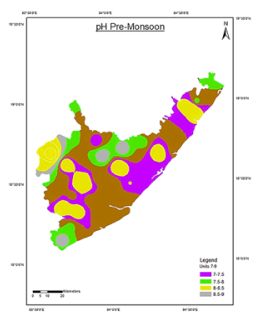

(a)

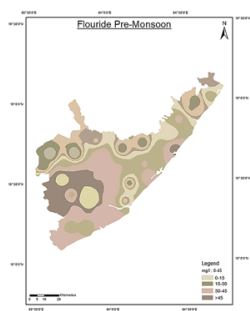

(g)

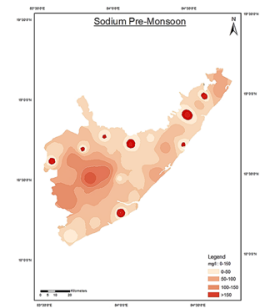

(m)

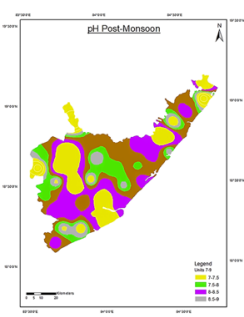

(b)

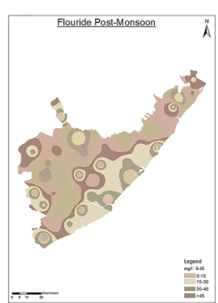

(h)

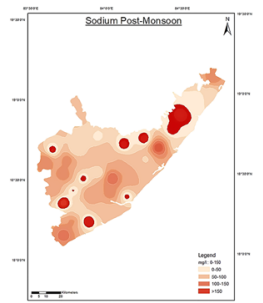

(n)

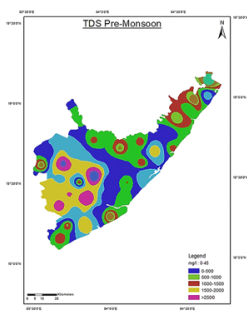

(c)

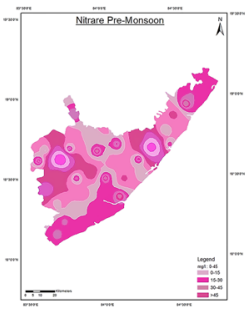

(i)

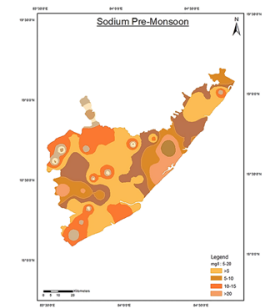

(o)

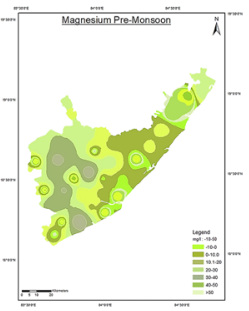

(s)

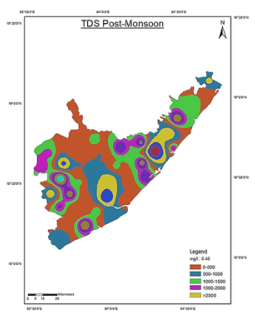

(d)

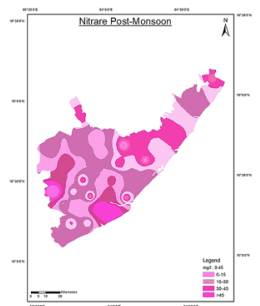

(j)

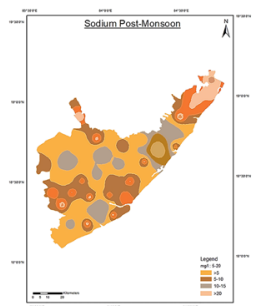

(p)

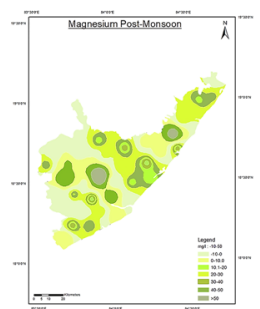

(t)

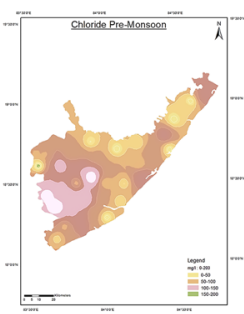

(e)

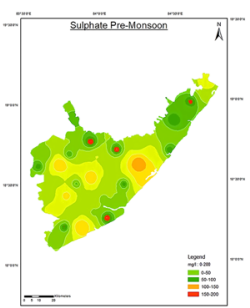

(k)

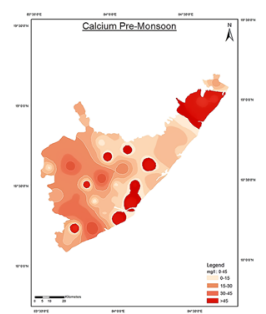

(q)

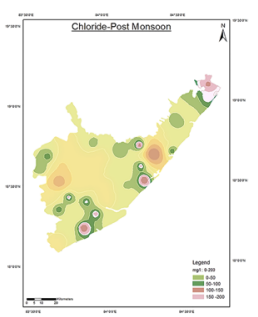

(f)

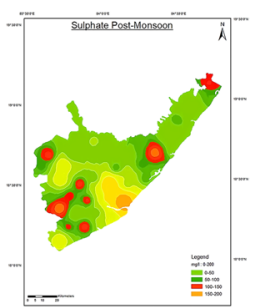

(l)

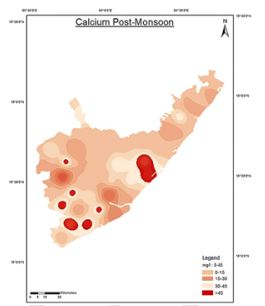

(r)

Fig. 4 Thematic maps of different elements of pre- and post-monsoon of 2017

$90 \mathrm{mg} / \mathrm{l}$ for prior to-rainfall season and 4.86 to $260 \mathrm{mg} / \mathrm{l}$ for the past-rainfall season. Few sampling sites reported magnesium concentrations above the standard desirable limit for both seasons. The classification of water quality parameter Magnesium is alienated into three categories according to BIS. These are most suitable for less than desirable value for drinking $(<30 \mathrm{mg} / \mathrm{l})$ and permissible for drinking (in between 30 and $100 \mathrm{mg} / \mathrm{l}$ ) and unsuitable for drinking is more significant than $100 \mathrm{mg} / \mathrm{l}$. Figures $3 \mathrm{~s}$ and $\mathrm{t}$ and $4 \mathrm{~s}$ and $\mathrm{t}$ show the spatial distribution of magnesium in both prior to and past-rainfall season.

\section{Water quality indices}

Adequate quantity and acceptable quality are essential parameters of water required for the sustenance of life. To appraise groundwater's suitability from current study area towards consumption, evaluation of water quality index using a weighted arithmetic index method has been carried out as per the methodology mentioned in Sect. (2.1.4). The status of water quality has been studied for thirty-eight Mandal headquarters of Srikakulam District.

Variation of WQI seasonally Low values of WQI imply that water does not have any pollutants arising from sampling 

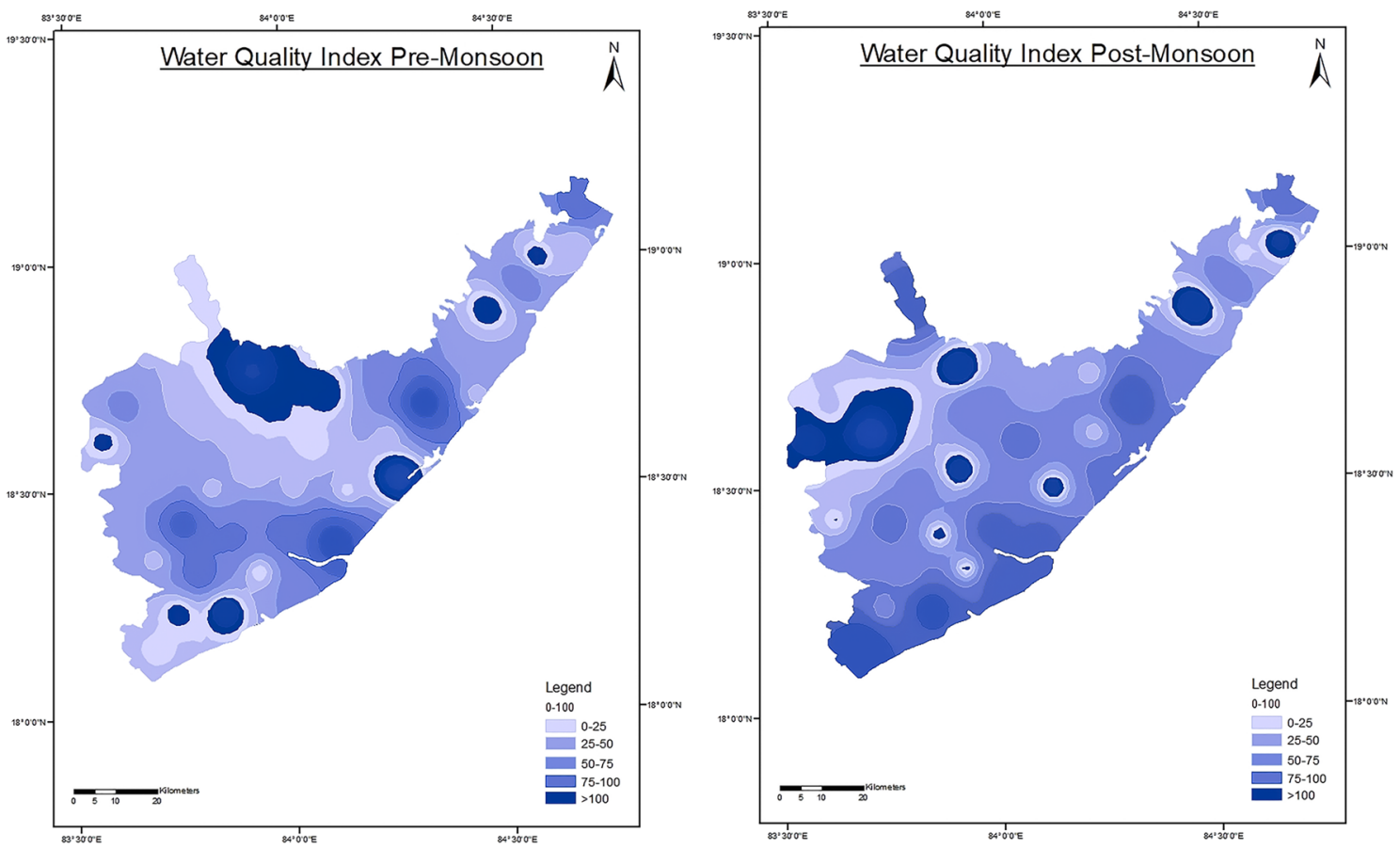

Fig. 5 Thematic Map of WQI for Prior to and Past Rainfall season in 2016
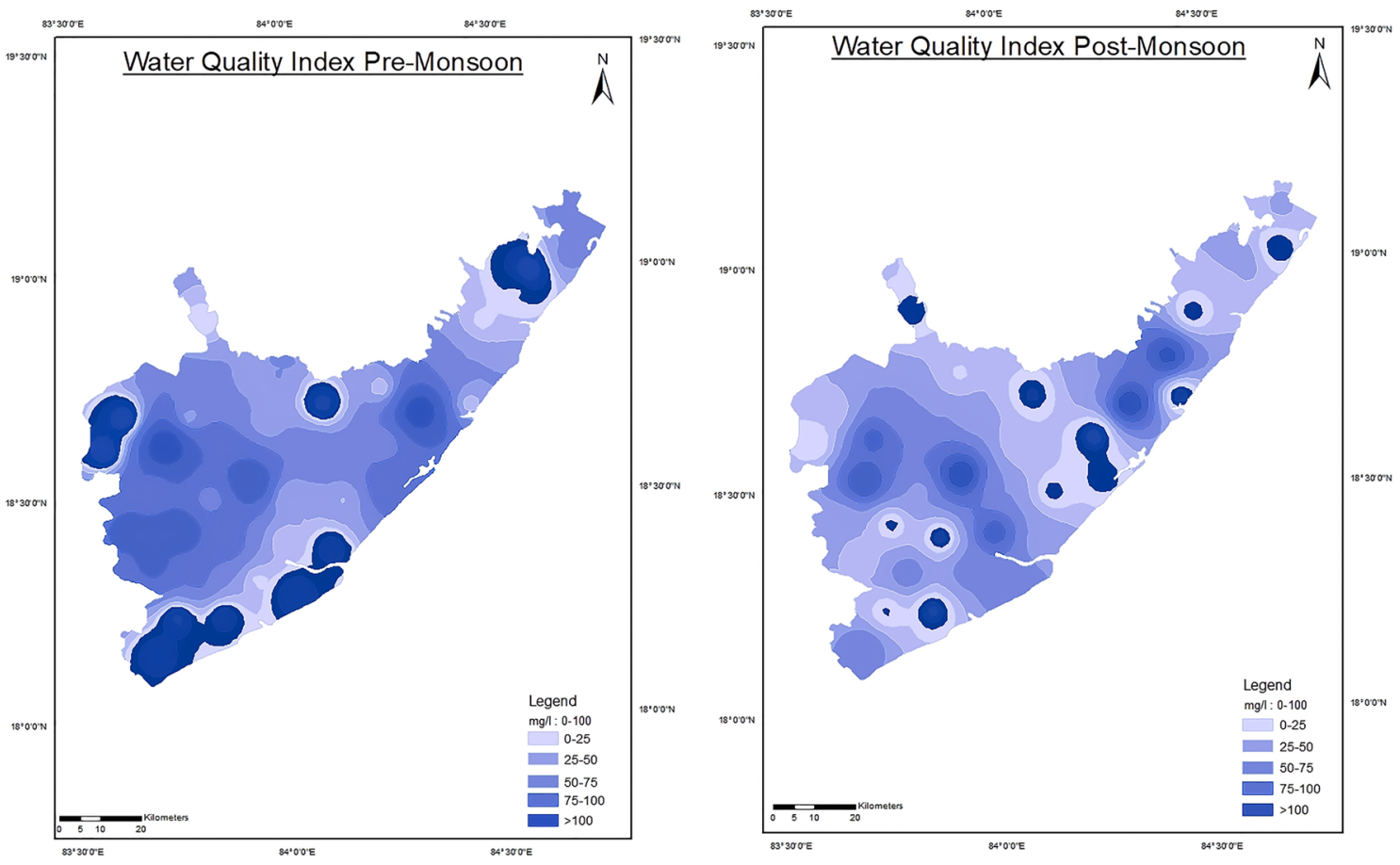

Fig. 6 Thematic Map of WQI for Prior to and Past-Rainfall season in 2017 


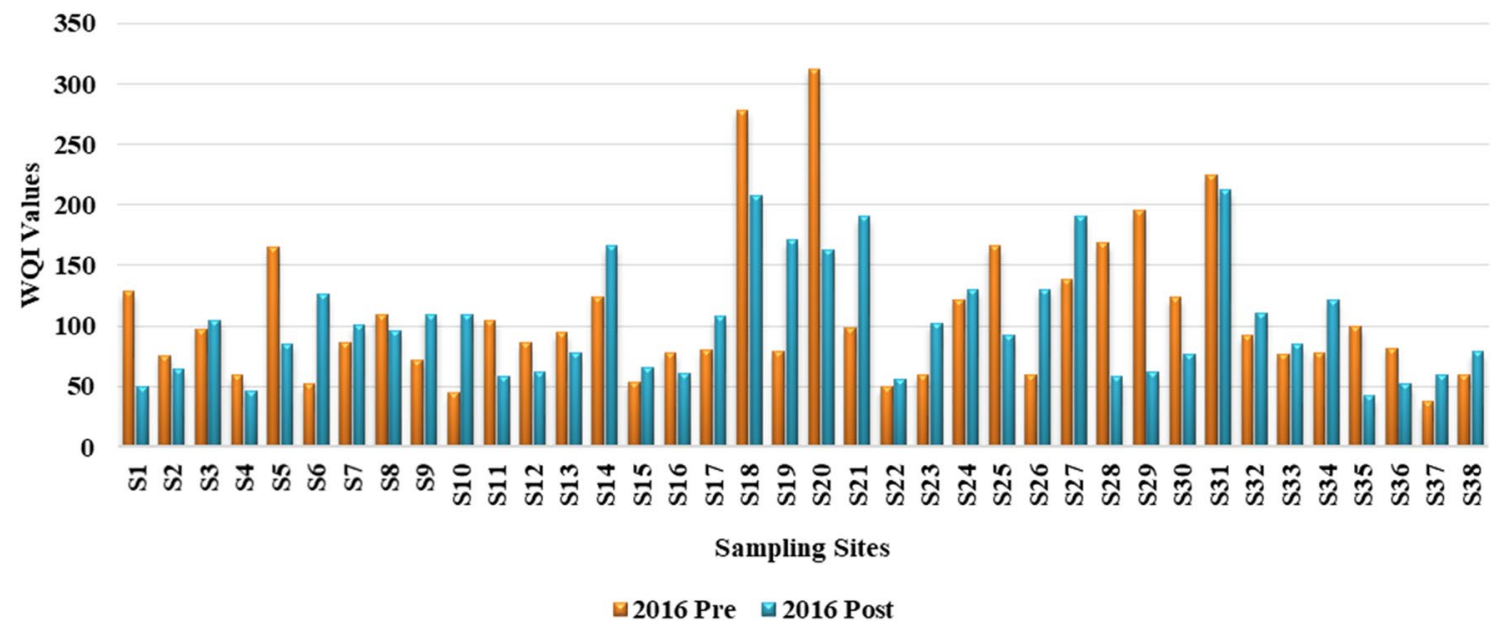

Fig. 7 Comparison of water quality index for prior to and past rainfall season for the year 2016

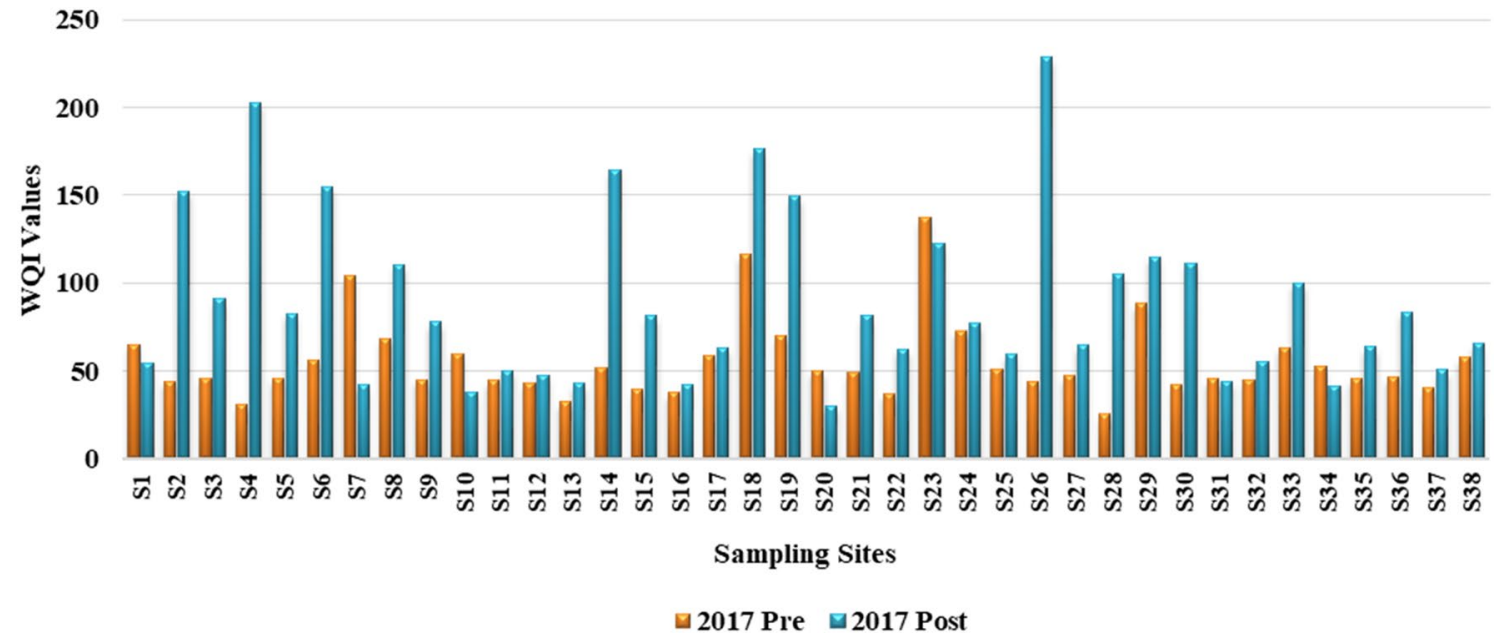

Fig. 8 Comparison of water quality index for prior to and past rainfall season for the year 2017

area. When WQI is significantly over 100 , it is found that water is polluted and unfit for consumption. WQI values for prior to and past-rainfall seasons are illustrated in Figs. 5 and 6 . Figure 5 is developed to indicate percentage disparities of diverse traits of water prior to and past-rainfall seasons. The study shows that the outcomes of the WQI values in prior to and past-rainfall seasons range from 37.53 to 312.46 , 42.04 to 211.89 , respectively, for the year 2016. Figure 6 illustrates the variations of other water attributes in prior to and past-rainfall seasons of 2017. WQI values prior to, pastrainfall seasons are in the range of 25.01 to $137.06,30.06$ to 228.83, respectively, for the year 2017. Using Microsoft Excel bar diagrams, Figs. 7 and 8 are generated to indicate the disparities of diverse water quality in prior to and pastrainfall seasons.

\section{Correlation coefficient (CC) matrix of water parameters}

$\mathrm{CC}$ of nearly 1 or -1 lies between -1 and +1 . Further, $\mathrm{CC}$ falling around zero implies none relationship, while positive relationship is indicated by positive values, and an inverse relationship is indicated by negative values of $r$. During prior to-Rainfall season (2016), Electric conductivity (E.C.) showed robust optimistic and significant correlation with $\mathrm{Na}+$, TDS, $\mathrm{Cl}-$ and showed a negative relation with magnesium. Magnesium showed a negative relationship with almost all parameters. All the remaining parameters showed a weak relationship with one another. In the year 2017 prior to-rainfall seasons, EC showed a strong relationship with TDS and Sulphate, whereas the remaining parameters showed an average relationship, while during the past-rainfall season, EC showed a strong 
relationship with $\mathrm{SO}_{4}, \mathrm{Cl}$ - and TDS, which led to strong relationships, whereas all remaining parameters showed weak relationships.

\section{Conclusions}

- From the analysis of prior to and past-rainfall season data and the average values obtained, it has been inferred that specific parameters like Calcium, Magnesium, TDS have increased. Remaining parameters like $\mathrm{pH}$, Chlorides, Fluorides, Nitrates showed a decrease in concentration, which is attributed to an increase in concentration due to more significant leaching and a reduction in concentration due to dilution.

- The spatial representation of quality of groundwater from study area is presented as final output, which indicates that subsurface water from the current study area requires some degree of treatment to be fit for consumption. Data from the present study enable understanding water quality and developing appropriate management steps to protect subsurface water sources.

- No fluoride-contaminated water was observed in the current study. Out of thirty-eight groundwater stations in the study area, ten stations show nitrate concentration more than $45 \mathrm{mg} / \mathrm{l}$ causing blue baby syndrome in infants. It is suggested to choose an alternative source of water supply.

- The method of Weighted Arithmetic Index was adopted for assessing the water quality status. WQI values of subsurface water samples for prior to and past-rainfall season seasons illustrate a slight alteration that are not noteworthy concerning potability and ground water quality. Trends along long-term for overall index values are understood to be challenging to calculate unless data for more years are available. Tendencies over more extended durations might be assessed for discrete water quality variables.

- As per the WQI scale, the selected stations from where groundwater was collected is classified on a scale from excellent to very poor and, in certain areas the quality of water was not fit for drinking. The highest value of WQI (312) is observed at S20 in Prior to-rainfall season (2016) and the minimum value of WQI (25.87) at S28 past-rainfall season.

Supplementary Information The online version contains supplementary material available at https://doi.org/10.1007/s13201-021-01506-1.

Funding The author(s) received no specific funding for this work.

\section{Declarations}

Conflict of interests The authors declare that they have no competing interests.

Open Access This article is licensed under a Creative Commons Attribution 4.0 International License, which permits use, sharing, adaptation, distribution and reproduction in any medium or format, as long as you give appropriate credit to the original author(s) and the source, provide a link to the Creative Commons licence, and indicate if changes were made. The images or other third party material in this article are included in the article's Creative Commons licence, unless indicated otherwise in a credit line to the material. If material is not included in the article's Creative Commons licence and your intended use is not permitted by statutory regulation or exceeds the permitted use, you will need to obtain permission directly from the copyright holder. To view a copy of this licence, visit http://creativecommons.org/licenses/by/4.0/.

\section{References}

Adimalla N (2021) Application of the entropy weighted water quality index (EWQI) and the pollution index of groundwater (PIG) to assess groundwater quality for drinking purposes: a case study in a rural area of Telangana State, India. Arch Environ Contam Toxicol 80(1):31-40

Adimalla N, Taloor AK (2020) Hydrogeochemical investigation of groundwater quality in the hard rock terrain of South India using geographic information system (GIS) and groundwater quality index (GWQI) techniques. Groundw Sustain Dev 10:100288

Adimalla N, Wu J (2019) Groundwater quality and associated health risks in a semi-arid region of south India: implication to sustainable groundwater management. Hum Ecol Risk Assess Int J 25(1-2):191-216

Adimalla N, Li P, Venkatayogi S (2018) Hydrogeochemical evaluation of groundwater quality for drinking and irrigation purposes and integrated interpretation with water quality index studies. Environ Process 5(2):363-383

Adimalla N, Dhakate R, Kasarla A, Taloor AK (2020) Appraisal of groundwater quality for drinking and irrigation purposes in Central Telangana, India. Groundw Sustain Dev 10:100334

Asano T, Cotruvo JA (2004) Groundwater recharge with reclaimed municipal wastewater: health and regulatory considerations. Water Res 38(8):1941-1951

Cortes JE, Muñoz LF, Gonzalez CA, Niño JE, Polo A, Suspes A, Trujillo $\mathrm{H}$ (2016) Hydrogeochemistry of the formation waters in the San Francisco field, UMV basin, Colombia-A multivariate statistical approach. J Hydrol 539:113-124

Dhar S, Rai AK, Nayak P (2017) Estimation of seismic hazard in Odisha by remote sensing and GIS techniques. Nat Hazards 86(2):695-709

Dişli E (2017) Hydrochemical characteristics of surface and groundwater and suitability for drinking and agricultural use in the Upper Tigris River Basin, Diyarbakır-Batman. Turkey Environ Earth Sci 76(14):1-23

Duraisamy S, Govindhaswamy V, Duraisamy K, Krishinaraj S, Balasubramanian A, Thirumalaisamy S (2019) Hydrogeochemical characterization and evaluation of groundwater quality in Kangayam taluk, Tirupur district, Tamil Nadu, India, using GIS techniques. Environ Geochem Health 41(2):851-873

Facchinelli A, Sacchi E, Mallen L (2001) Multivariate statistical and GIS-based approach to identify heavy metal sources in soils. Environ Pollut 114(3):313-324 
Falkenmark M, Rockström J (2006) The new blue and green water paradigm: breaking new ground for water resources planning and management. J Water Resour Plann Manage 132(3):129-132

Gautam PK, Biswas A (2016) 2D Geo-electrical imaging for shallow depth investigation in Doon Valley Sub-Himalaya, Uttarakhand. India Model Earth Syst Environ 2(4):1-9

Gautam PK, Arora S, Kannaujiya S, Singh A, Goswami A, Champati PK (2017) A comparative appraisal of ground water resources using GRACE-GPS data in highly urbanised regions of Uttar Pradesh. India Sustain Water Resour Manage 3(4):441-449

Jakeman AJ, Barreteau O, Hunt RJ, Rinaudo JD, Ross A, Arshad M, Hamilton S (2016) Integrated Groundwater Management: An Overview of Concepts And Challenges. In: Jakeman Anthony J, Barreteau Olivier, Hunt Randall J, Rinaudo Jean-Daniel, Ross Andrew (eds) Integrated groundwater management. Springer, Cham, pp 3-20

Jasrotia AS, Kumar A (2014) Estimation of replenishable groundwater resources and their status of utilization in Jammu Himalaya, J\&K, India. Eur Water 48:17-27

Jasrotia AS, Bhagat BD, Kumar A, Kumar R (2013) Remote sensing and GIS approach for delineation of groundwater potential and groundwater quality zones of Western Doon Valley, Uttarakhand India. J Indian Soc Remote Sens 41(2):365-377

Jasrotia AS, Taloor AK, Andotra U, Bhagat BD (2018) Geoinformatics based groundwater quality assessment for domestic and irrigation uses of the Western Doon valley, Uttarakhand India. Groundw Sustain Dev 6:200-212

Jasrotia AS, Taloor AK, Andotra U, Kumar R (2019) Monitoring and assessment of groundwater quality and its suitability for domestic and agricultural use in the Cenozoic rocks of Jammu Himalaya, India: a geospatial technology-based approach. Groundw Sustain Dev 8:554-566

Jha MK, Shekhar A, Jenifer MA (2020) Assessing groundwater quality for drinking water supply using hybrid fuzzy-GIS-based water quality index. Water Res 179:115867

Karnena MK, Saritha V (2019) Evaluation of spatial variability in ground water quality using remote sensing. Int J Recent Technol Eng 8(2):4269-4278

Karunanidhi D, Aravinthasamy P, Subramani T, Muthusankar G (2021) Revealing drinking water quality issues and possible health risks based on water quality index (WQI) method in the Shanmuganadhi River basin of South India. Environ Geochem Health 43(2):931-948

Palanisamy PN, Geetha A, Sujatha M, Sivakumar P, Karunakaran K (2007) Assessment of ground water quality in and around Gobichettipalayam town Erode district Tamilnadu. J Chem 4(3):434-439

Patel P, Bablani S, Patel A (2020) Impact assessment of urbanization and industrialization using water quality index on Sabaramati river, Ahmedabad. SSRN Electron J. https://doi.org/10.2139/ ssrn. 3553800
Raju NJ, Patel P, Reddy BSR, Suresh U, Reddy TVK (2016) Identifying source and evaluation of hydrogeochemical processes in the hard rock aquifer system: geostatistical analysis and geochemical modeling techniques. Environ Earth Sci 75(16):1-23

Ram A, Tiwari SK, Pandey HK, Chaurasia AK, Singh S, Singh YV (2021) Groundwater quality assessment using water quality index (WQI) under GIS framework. Appl Water Sci 11(2):1-20

Rupal M, Tanushree B, Sukalyan C (2012) Quality characterization of groundwater using water quality index in Surat City, Gujarat. India Int J Environ Sci 1(4):14-23

Sakram G, Adimalla N (2018) Hydrogeochemical characterization and assessment of water suitability for drinking and irrigation in crystalline rocks of Mothkur region, Telangana State South India. Appl Water Sci 8(5):1-21

Silva MI, Gonçalves AML, Lopes WA, Lima MTV, Costa CTF, Paris M, De Paula Filho FJ (2021) Assessment of groundwater quality in a Brazilian semiarid basin using an integration of GIS water quality index and multivariate statistical techniques. J Hydrol 598:126346

Singh CK, Kumar A, Shashtri S, Kumar A, Kumar P, Mallick J (2017) Multivariate statistical analysis and geochemical modeling for geochemical assessment of groundwater of Delhi. India J Geochem Explor 175:59-71

Sinha MK, Rajput P, Baier K, Azzam R (2021) GIS-Based Assessment of Urban Groundwater Pollution Potential Using Water Quality Indices. In: Pande Chaitanya B, Moharir Kanak N (eds) Groundwater resources development and planning in the semi-arid region. Springer, Cham, pp 293-313

Taloor AK, Kotlia BS, \& Kumar K (Eds.) (2021) Water, Cryosphere, and Climate Change in the Himalayas: A Geospatial Approach. Springer Nature.

Tharani K, Abhilash PT (2021) A GIS-based approach to assess groundwater quality in Kurnool district. Sustain Water Resour Manag 7(2): $1-8$

Verma P, Singh PK, Sinha RR, Tiwari AK (2020) Assessment of groundwater quality status by using water quality index (WQI) and geographic information system (GIS) approaches: a case study of the Bokaro district. India Appl Water Sci 10(1):1-16

Zhang Q, Xu P, Qian H (2020) Groundwater quality assessment using improved water quality index (WQI) and human health risk (HHR) evaluation in a semi-arid region of northwest China. Expo Health 12(3):487-500

Zotou I, Tsihrintzis VA, Gikas GD (2020) Water quality evaluation of a lacustrine water body in the mediterranean based on different water quality index (WQI) methodologies. J Environ Sci Health C Part A 55(5):537-48

Publisher's Note Springer Nature remains neutral with regard to jurisdictional claims in published maps and institutional affiliations. 